\title{
A cell line (NTU-MV) established from Maruca vitrata (Lepidoptera: Pyralidae): Characterization, viral susceptibility, and polyhedra production
}

\author{
Shih-Chia Yeh ${ }^{\text {a }}$, Song-Tay Lee ${ }^{\mathrm{b}}$, Chih-Yu Wu ${ }^{\text {a }}$, Chung-Hsiung Wang ${ }^{\mathrm{a}, *}$ \\ ${ }^{a}$ Department of Entomology, National Taiwan University, Taipei, Taiwan, ROC \\ ${ }^{\mathrm{b}}$ Department of Biotechnology, Southern Taiwan University of Technology, Tainan, Taiwan, ROC
}

Received 30 November 2006; accepted 16 April 2007

Available online 21 April 2007

\begin{abstract}
Here we describe the establishment of a new cell line, NTU-MV, derived from pupal tissues of an economically important pest, the legume pod borer Maruca vitrata. This cell line contained four major cell types: polymorphic cells, round cells, spindle-shaped cells, and comma cells. The doubling time of MV cells in TNM-FH medium supplemented with $8 \%$ FBS at $28{ }^{\circ} \mathrm{C}$ was $27 \mathrm{~h}$. The chromosome numbers of MV cells varied widely from 16 to 268. Compared to other insect cell lines, the MV cell line produced distinct isozyme patterns with esterase, malate dehydrogenase (MDH), and lactate dehydrogenase ( $\mathrm{MDH})$. Confirmation that NTU-MV was derived from $M$. vitrata was demonstrated by showing that the sequence of the internal transcribed spacer regions (ITS) of the MV cells was $98 \%$ identical to that of M. vitrata larvae. Two NTU-MV cell strains, NTU-MV1 and NTU-MV56, were selected based on susceptibility to MaviMNPV ( $M$. vitrata multiple nucleopolyhedrovirus). NTU-MV, MV1, and MV56 cells showed a high susceptibility to MaviMNPV and produced high yields of polyhedra (47-50 OBs/cell, $\left.4 \times 10^{7}-5.96 \times 10^{7} \mathrm{OBs} / \mathrm{ml}\right)$ after 2 weeks of MaviMNPV infection. We conclude that the NTU-MV cell line will be a useful tool for studying MaviMNPV as well as for the mass production of MaviMNPV polyhedra for the biocontrol of $M$. vitrata.
\end{abstract}

(C) 2007 Elsevier Inc. All rights reserved.

Keywords: Maruca vitrata; MaviMNPV; Cell line; Characterization; Nucleopolyhedrovirus

\section{Introduction}

Since Grace (1962) first established an insect cell line, more than 500 insect cell lines have been developed from 120 different insects. These cell lines are widely used in basic and applied studies, but many important pest species are not represented (Hink, 1970; Lynn, 2001). In particular, to date there are only a few permissive cell lines for in vitro propagation of baculoviruses (Wang et al., 1996; Wu et al., 1989; Wu and Wang, 2006).

Baculoviruses have only been isolated from arthropods, primarily from insects of the order Lepidoptera. The Baculoviridae family consists of two genera, Nucleopoly-

\footnotetext{
${ }^{*}$ Corresponding author. Fax: +886227364329.

E-mail address: wangch@ccms.ntu.edu.tw (C.-H. Wang).
}

hedrovirus (NPV) and Granulovirus (GV), and 42 species from over 600 baculovirus isolates have been defined. The $28 \mathrm{NPV}$ species are characterized by the presence of large occlusion bodies (OBs) in which numerous virions are occluded (Theilmann et al., 2005). Most NPVs have a narrow host range and do not attack nontarget organisms; in particular, they do not attack vertebrates, which makes them useful in pest control and as expression vectors for foreign genes.

The legume pod borer, Maruca vitrata (Geyer) (Lepidoptera: Pyralidae), is distributed around tropical and subtropical Africa, Asia, and the Pacific (Booker, 1965; Passlow, 1968; Taylor, 1967; Koehler and Metha, 1972; Singh and van Emden, 1979). This insect is a serious pest to economically important legumes. The larvae bore into buds, blossoms, and flowers and then spin silken 
threads which tangle together to restrain the blossoms and pods, and mechanically restrict pod growth (Saxena, 1978; Huang et al., 2003). This causes yield losses of up to $80 \%$ (Singh et al., 1990; Afun et al., 1991; Dreyer et al., 1994). In Taiwan, M. vitrata is a major pest of the yard long bean, Vigna sesquipedalis, and it has recently caused increasing damage to the tropical legume, Sesbania cannabina (Retsz.) Pers., which is grown as a green manure crop during the summer (Huang and Peng, 2001). Since S. cannabina is not an economically important crop, in general no pesticide treatments are applied by farmers in Taiwan. Unfortunately, this has led to an increase in the population of $M$. vitrata, and this pest has now become a more serious threat to other commercially grown legumes. In Taiwan in the spring of 2004, an NPV-inducing epizootic of $M$. vitrata larvae occurred in a field of $S$. cannabina. The causative agent was a baculovirus, which was named MaviMNPV ( $M$. vitrata multiple nucleopolyhedrovirus) (AVRDC, 2005). Until now, there have been no permissive cell lines for MaviMNPV propagation. Here we describe the successful establishment of a permissive cell line derived from the pupal ovary tissues of $M$. vitrata. We also show that this cell line and two of its stains have a high susceptibility to MaviMNPV and produce a high yield of occlusion bodies (OBs).

\section{Materials and methods}

\subsection{Primary culture and subculture}

Maruca vitrata pupae were collected from Tainan, Taiwan. The surfaces of the pupae were sterilized by washing first with 10\% Clorox solution and then with $70 \%$ iodine alcohol. The pupal ovary tissues were removed with a fine forceps and a pipet, and incubated at $28^{\circ} \mathrm{C}$ in a $25 \mathrm{~cm}^{2}$ flask with $4 \mathrm{ml}$ of TNM-FH medium (Hink and Strauss, 1976) containing $100 \mathrm{IU} / \mathrm{ml}$ penicillin, $100 \mu \mathrm{g} / \mathrm{ml}$ streptomycin, and $1.25 \mu \mathrm{g} / \mathrm{ml}$ fungizone. The medium was supplemented with $16 \%$ fetal bovine serum (FBS) that had been inactivated at $56^{\circ} \mathrm{C}$ for $30 \mathrm{~min}$.

When the cells approached confluence, they were subcultured by resuspending growing cells with vigorous agitation and transferring $1 \mathrm{ml}$ of the suspended cells to another $25 \mathrm{~cm}^{2}$ flask containing $4 \mathrm{ml}$ of fresh medium plus supplements. From the initial subculture to the 40th passage, the interval between subcultures ranged from 1 to 3 weeks, depending on the growth rate of the cells. After the 49th passage, the cells propagated rapidly, and thereafter the interval between passages was 3-4 days. The resulting cell line was designated NTU-MV.

\subsection{Cell strains of $N T U-M V$ cells}

The MV cells were diluted to an average density of 2 cells per $0.1 \mathrm{ml}$. After dilution, $0.05 \mathrm{ml}$ cell suspension was plated in each well of a 96-well plate and then supplemented with $0.05 \mathrm{ml}$ of conditioned medium (filtered med- ium from a 2- to 3-day-old culture of Sf9 cells) and $0.05 \mathrm{ml}$ TNM-FH medium. After 2 weeks, the cell colonies were transferred to 24-well culture plates and their susceptibility to MaviMNPV was tested.

\subsection{Growth rate of $N T U-M V$ cells}

To measure growth rate, MV cells were seeded in $25 \mathrm{~cm}^{2}$ flasks at a density of $5 \times 10^{6}$ cells per flask. Different media (TNM-FH supplemented with $0 \%, 4 \%$, $8 \%$, and $16 \% \mathrm{FBS}$, and serum-free Sf900 medium [Invitrogen, USA]) were added. The cells were then incubated at $28^{\circ} \mathrm{C}$. Cell number was determined by counting the numbers within a microscope reticule of which the area at a certain objective was known. The cell densities in five areas of each flask were determined at $24 \mathrm{~h}$ intervals for 5 days incubation.

\subsection{Chromosome number}

Log phase NTU-MV cells $\left(1.8 \times 10^{7}\right.$ cells $)$ were treated with $1 \mathrm{ml}(1.5 \mu \mathrm{g} / \mu \mathrm{l})$ demecolcine (Sigma, D-6279) for $4 \mathrm{~h}$ at $28{ }^{\circ} \mathrm{C}$. The cells were then dispersed and centrifuged at $65 \mathrm{~g}$ (Hettich Universal $30 \mathrm{~F} / \mathrm{RF}$ ) for $10 \mathrm{~min}$, resuspended for $40 \mathrm{~min}$ in a hypotonic solution of normal saline and distilled water in a 1:4 dilution, and then fixed in 3:1 methanol:glacial acetic acid for $10 \mathrm{~min}$. The fixing process was repeated five times, and the fixed cells were dropped vertically onto slides. After drying at $37^{\circ} \mathrm{C}$ in an incubator, the cells were stained with Giemsa stain for $7 \mathrm{~min}$ and the chromosome number was counted under a microscope.

\subsection{Isozyme analysis}

The isozyme patterns of confluent cells of NTU-MV and two of its MaviMVPV-permissive strains (NTU-MV1 and NTU-MV56) were compared with those of NTU-PN-HF (Perina nuda cell line; Wu et al., 2002), IPLB-LD-652Y (Lymantria dispar cell line; Goodwin et al., 1978), and Sf9 (Spodoptera frugiperda cell line). The HF, LD, MV, MV1, and MV56 cells were cultured in TNM-FH supplemented with $8 \%$ FBS. The Sf9 cells and another culture of MV cells were cultured in serum-free Sf900 medium. At confluence, the cells were scraped, counted, and then centrifuged at $80 \mathrm{~g}$ (Hettich Universal 30F/RF) for $10 \mathrm{~min}$ at $4{ }^{\circ} \mathrm{C}$. The supernatants were discarded and the pellets were resuspended in $\mathrm{ddH}_{2} \mathrm{O}$ to a concentration of $1.8 \times 10^{7} / \mathrm{ml}$. The suspended cells were lysed by freezing in liquid nitrogen and thawing at $37^{\circ} \mathrm{C}$ five times then centrifuged at $90 \mathrm{~g}$ (KUBOTA 1300) for $10 \mathrm{~min}$. The resulting supernatants were stored at $-20^{\circ} \mathrm{C}$. Next, the supernatants were electrophoresed on $10 \%$ polyacrylamide gels at a constant voltage of $50 \mathrm{~V}$ for $6 \mathrm{~h}$. The cells were then tested for three isozymes, esterase, lactate dehydrogenase (LDH), and malate dehydrogenase $(\mathrm{MDH})$, using the staining protocols of Manchenko (2003). 


\subsection{Internal transcribed spacer (ITS) region}

The DNAs of the larvae of $M$. vitrata, NTU-MV cells, and Sf9 cells were extracted using a commercial kit (Genemark $^{\circledR}$ Tissue \& Cell Genomic DNA Purification Kit). The ITSI region was amplified by the primers, ITS1-1: $5^{\prime}-\mathrm{CCC}$ CATAAACGAGGAATTCC- $3^{\prime}$ and ITS1-2: 5'-GCAGT TCACACTATGACGCGC- $3^{\prime}$. The ITSII region was amplified by the primers ITS2-1: 5'-GCGCGTCATAGT GTGAACTGC- $3^{\prime}$ and ITS2-2:5'-TCCTCCGCTTATTG ATATGC-3' (Fig. 1). The primers ITS1-1, ITS1-2, and ITS2-1 were designed by H.F. Lin (unpublished data). The primer ITS2-2 was designed by White et al. (1990). PCR conditions were: $94{ }^{\circ} \mathrm{C}, 2 \mathrm{~min}$ for the initial cycle; followed by 40 cycles of: $94{ }^{\circ} \mathrm{C}, 15 \mathrm{~s} ; 60^{\circ} \mathrm{C}$ (ITSI) $/ 56{ }^{\circ} \mathrm{C}$ (ITSII), $30 \mathrm{~s} ; 68^{\circ} \mathrm{C} 3 \mathrm{~min}$. The PCR products were commercially sequenced (Seeing Bioscience Company), and ClustalX1.81 was used to analyze the identity of the ITS regions among the $\mathrm{MV}$ and $\mathrm{Sf} 9$ cells, and the $M$. vitrata larvae.

\subsection{Viral susceptibility}

The following viruses were used to test the viral susceptibility of NTU-MV cells: AcMNPV (Autographa californica NPV) supplied by Dr. M.J. Fraser of Notre Dame University; LdNPV (Lymantria dispar NPV)-like virus, LyxyNPV (Lymantria xylina NPV) collected from infected larvae of $L$. xylina, PenuNPV (Perina nuda NPV) collected from infected larvae of $P$. nuda, and MaviMNPV collected from infected larvae from the Sesbania fields in southern Taiwan. The infected insect was homogenized in TNMFH medium and centrifuged at $1250 \mathrm{~g}$ for $10 \mathrm{~min}$. The supernatant was filtered with $0.2 \mu \mathrm{m}$ sterilized filter. The filtrates were the sources of the virus inocula. For the first four viruses, four permissive cell lines, Sf9, LD7 (the cell strain of the IPLB-LD652Y cell lines), LY (Wu and Wang, 2006), and NTU-PN-HH (Wang et al., 1996) were used as positive controls. These cell lines and the MV cell line were also tested for MaviMNPV susceptibility. Virus titers were determined by the end-point dilution method (TCID $_{50}$ analysis) (Summers and Smith, 1988).

\subsection{Infection rate of $M V$ cells with MaviMNPV}

Preparations of MaviMNPV ( $500 \mu \mathrm{l}$; MOI $=1)$ were used to infect cell cultures $\left(\sim 5 \times 10^{6}\right.$ cells $)$ of MV, MV1, and MV56 cells in 8\% FBS, and MVSf900 cells cultured in Sf900 medium. The cultures were incubated at $28^{\circ} \mathrm{C}$, and the percentages of infected cells were counted daily by microscope until the cells lysed.

\subsection{Production of occlusion bodies and extracellular virus}

Preparations of MaviMNPV ( $25 \mu \mathrm{l}$; MOI $=0.5$ ) were used to infect MV cells $\left(\sim 6 \times 10^{6}\right.$ cells $)$ cultured either in $5 \mathrm{ml}$ TNM-FH medium with $4 \%, 6 \%, 8 \%$, and $10 \%$ FBS or in $5 \mathrm{ml}$ serum-free Sf900 medium. MV1 and MV56 cells were also infected and cultured in TNM-FH medium with $8 \%$ FBS. The cell cultures were incubated at $28^{\circ} \mathrm{C}$, and at 1 or 2 weeks postinfection, RIPA lysis buffer $(150 \mathrm{mM} \mathrm{NaCl}$, $1 \%$ NP-40, $0.5 \%$ deoxyochoic acid, $0.1 \%$ sodium dodecyl sulfate, and $50 \mathrm{mM}$ Tris) and scraping were used to remove the cells from the surface of the flask. The suspension of lysed cells was then centrifuged at $1250 \mathrm{~g}$ (Hettich Universal $30 \mathrm{~F} / \mathrm{RF}$ ) for $15 \mathrm{~min}$. The titers of the extracellular virus (ECV) were determined by the end-point dilution method (TCID $_{50}$ analysis). The occlusion bodies (OBs) were resuspended with $4 \mathrm{ml}$ of $\mathrm{ddH}_{2} \mathrm{O}$ and then counted by hemacytometer.

\subsection{Electron microscopy}

At 3 days postinfection, MV cells infected with MaviMNPV and cultured in $8 \%$ FBS were scraped from the surfaces of flasks and centrifuged at $80 \mathrm{~g}$ (Hettich Universal 30F/RF). The supernatant was discarded and the pellet was fixed in 5\% glutaraldehyde in $\mathrm{pH} 7.2$ phosphate buffer for $4 \mathrm{~h}$ and postfixed with $\mathrm{OsO}_{4}$ in the same buffer at $4{ }^{\circ} \mathrm{C}$ for $3 \mathrm{~h}$. The pellet was dehydrated in an alcohol gradient series $(70-100 \%)$ and embedded in Spurr Epon. Thin sections were cut on a Reichert OMU 3 ultramicrotome and stained with uranyl acetate and lead citrate. The photomicrographs were made with a Hitachi H7100 electron microscope at $100 \mathrm{kV}$.

\subsection{RELP (restriction endonuclease length polymorphism) of viral DNAs}

MaviMNPV polyhedra were isolated and purified from infected MV cells and moribund $M$. vitrata larvae by following the methods of $\mathrm{Wu}$ and Wang (2005). The respective DNAs were extracted and then digested with EcoRI, HindIII, and PstI (Promega Corporation)

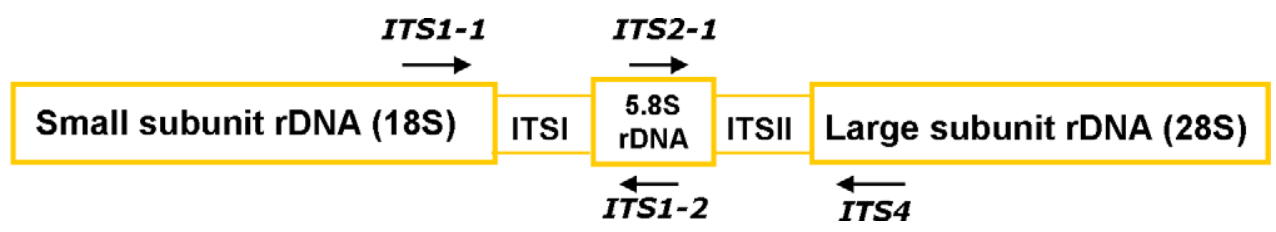

Fig. 1. Location of the internal transcribed spacers (ITS) region and the primers for ITSI and ITSII. 
according to the user's manual, and analyzed in $0.8 \%$ agarose gels.

\section{Results}

\subsection{Morphology of MV cells}

A primary culture of pupal ovary cells of $M$. vitrata (Fig. 2A) was used to establish the NTU-MV cell line in vitro (Fig. 2B). The MV cells have now been passaged for more than 2 years in TNM-FH medium containing $8 \% \mathrm{FBS}$ at a constant temperature of $28^{\circ} \mathrm{C}$. The cell line contains four major cell types, polymorphic, round, spindle-shaped, and comma, that were already persistent after 50 passages. The characteristics of these four cell types are as follows:

The polymorphic cells are irregular in shape, vary in size $(50.7 \pm 12.6 \mu \mathrm{m}$ [width $\pm \mathrm{SD}])$ and attach firmly to the flask. The round cells are the smallest cell type, attach loosely to the flask, and have an average diameter of $15.5 \pm 2.1 \mu \mathrm{m}$. The spindle-shaped cells are predominantly ellipsoidal with two extensions on opposite sides. They attach firmly to the flask, and vary in size $(66.3 \pm 20.7 \mu \mathrm{m}$ in length and $10.4 \pm 2.4 \mu \mathrm{m}$ in width). The comma cells attach firmly to the flask, have only one extension, and are $39.8 \pm 9.3 \mu \mathrm{m}$ in length and $9.2 \pm 1.9 \mu \mathrm{m}$ in width. The polymorphic cells are the most common cell type $(35.4 \%)$, followed by the round cells $(30 \%)$, the spindle-shaped cells $(20 \%)$, and the comma cells $(14.6 \%)$.

\subsection{Cell strains of NTU-MV cells}

Two MV cell strains, NTU-MV1 and NTU-MV56, were selected from more than 100 cell colonies based on their susceptibility to MaviMNPV. Both of these cell strains also contain four cell types. In MV1 cells, the polymorphic cells are the most common $(36.5 \%)$, followed by round cells $(23.5 \%)$, spindle-shaped cells $(22 \%)$, comma cells $(18 \%)$ (Fig. 2C). The mean sizes of round, spindle-shaped, polymorphic, and comma cells are, respectively, 17, $84.9 \times 11.6,60.5$, and $48.8 \times 10.7 \mu \mathrm{m}$.

In NTU-MV56 cell strains, round cells are the most common cell type $(82 \%)$, followed by polymorphic cells $(10.7 \%)$, spindle-shaped cells $(4.6 \%)$, and comma cells $(2.7 \%)$ (Fig. 2D). The mean sizes of round, spindle-shaped, polymorphic, and comma cells are, respectively, 16.5, $58.1 \times 10.4,43$, and $43 \times 11.1 \mu \mathrm{m}$.

\subsection{Growth rate of NTU-MV cells}

The growth rates of NTU-MV cells were fastest in medium supplemented with 8 and 16\% FBS (Fig. 3). The doubling times of MV cells cultured in medium supplemented with $0 \%, 4 \%, 8 \%$, and $16 \%$ FBS at $28^{\circ} \mathrm{C}$ were 46.53 , $33.29,27.76$, and $27.24 \mathrm{~h}$, respectively. Doubling time in Sf900 medium was $37.47 \mathrm{~h}$.

\subsection{Chromosome number}

The chromosomal spread from NTU-MV cells shows the typical round shape of the Lepidopteran chromosome (Fig. 4A). Chromosome number distribution varied widely from 16 to 268 with a mode of 40 (Fig. 4B).

\subsection{Isozyme analysis}

MV, MV1, and MV56 cells produced identical isozyme patterns for esterase, $\mathrm{MDH}$, and $\mathrm{LDH}$, and these patterns were distinct from those produced by HF, LD, and Sf9 cells
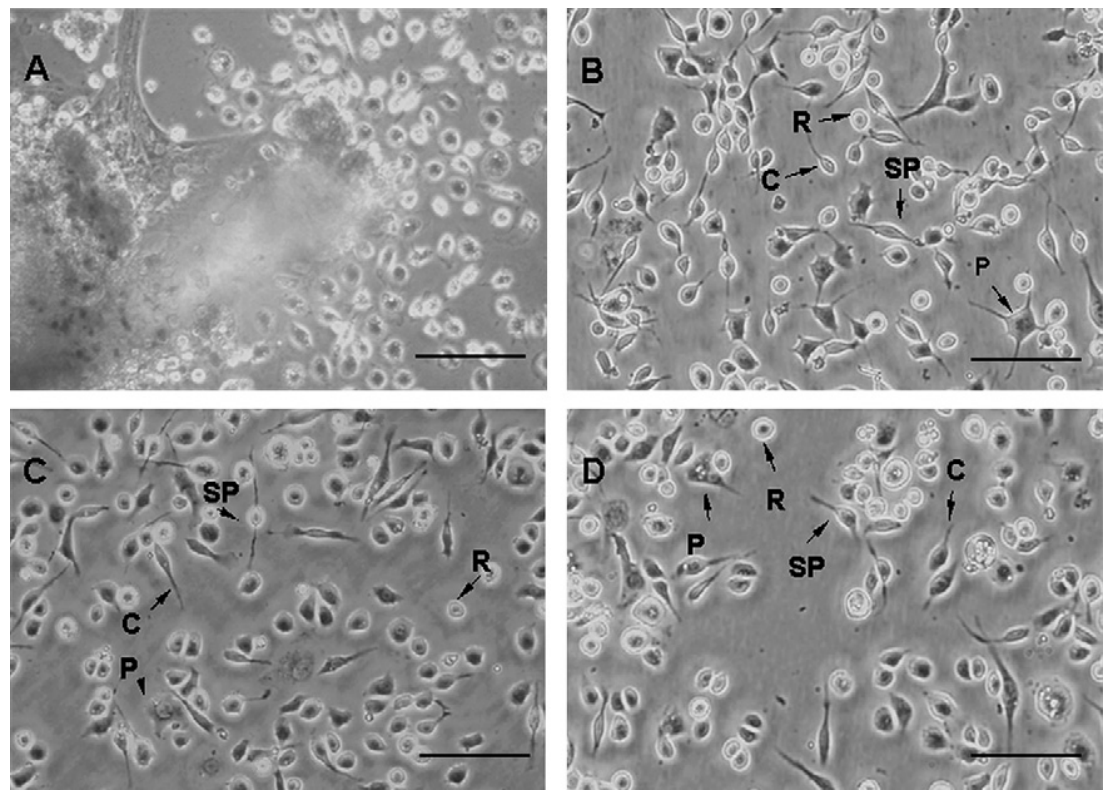

Fig. 2. (A) Primary culture of Maruca vitrata pupal ovary tissues. (B), (C) and (D) the NTU-MV, NTU-MV1, and NTU-MV56 cell lines, respectively, after plating for $6 \mathrm{~h}$. P, polymorphic cells; R, round cells; SP, spindle-shaped cells; C, comma cells. Bar: $50 \mu \mathrm{m}$. 


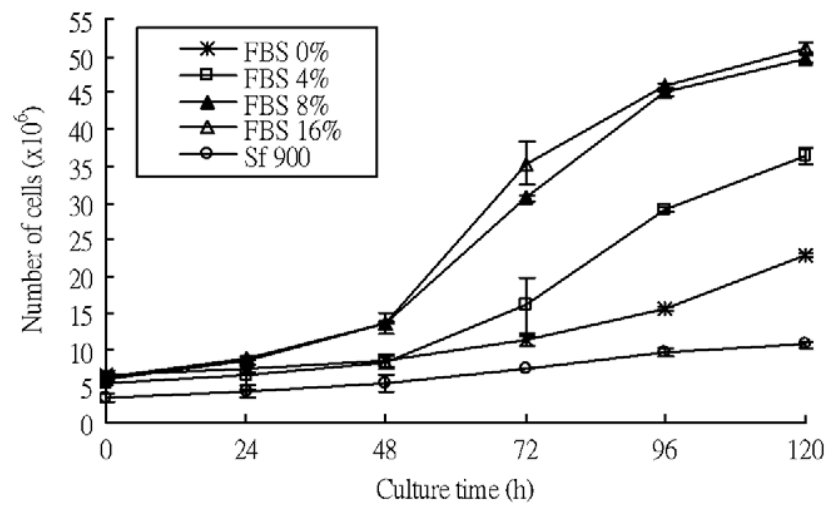

Fig. 3. The growth curves of NTU-MV cells cultured at $28^{\circ} \mathrm{C}$ in TNMFH medium supplemented with $0 \%, 4 \%, 8 \%$, and $16 \%$ FBS, respectively, and in Sf900 medium.

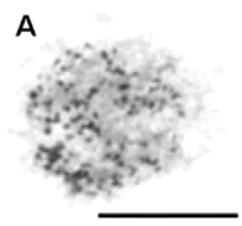

B

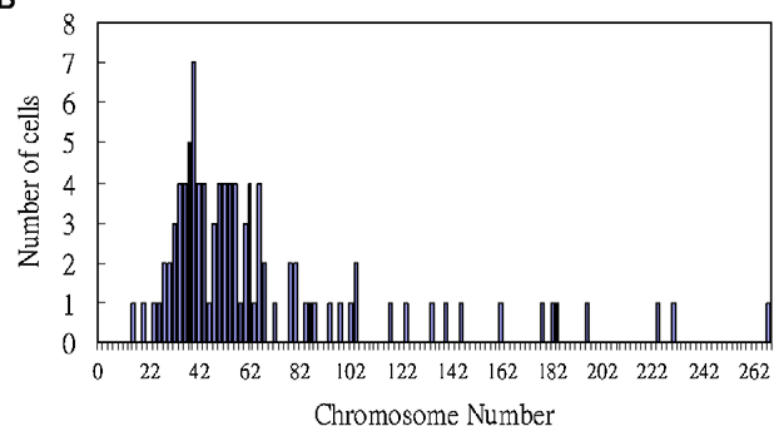

Fig. 4. (A) Representative mitotic chromosomal spread of an NTU-MV cell. Bar: $12.5 \mu \mathrm{m}$ and (B) Chromosome number distribution in the NTUMV cell population.

(Fig. 5). MV cells in Sf900 medium also produced the same pattern, but we note that there was a rapid degradation of the LDH isozyme produced by cells cultured in this medium. After storage of MV/Sf 900 cell extracts at $-20^{\circ} \mathrm{C}$ for 1 week, no $\mathrm{LDH}$ pattern could be detected (data not shown).

\subsection{Internal transcribed spacer (ITS) region}

The identity of the sequences of the internal transcribed spacer (ITS) regions of $M$. vitrata and NTU-MV cells was $\sim 98 \%$. This compares to an ITS identity of only $60 \%$ between $M$. vitrata and $\mathrm{Sf} 9$ cells.

\subsection{Virus susceptibility}

In $8 \%$ FBS TNM-FH medium, NTU-MV, MV1 and MV56 cells all showed a high susceptibility to MaviMNPV in vitro (Fig. 6). The figure also shows that infection rates in

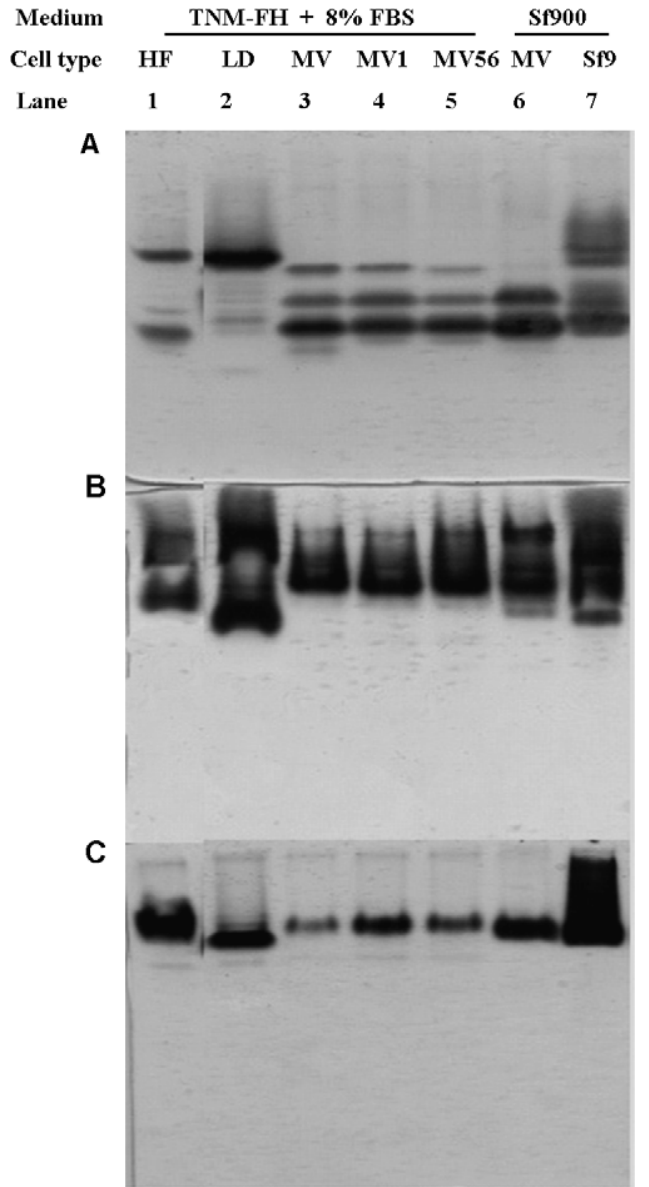

Fig. 5. The isozyme patterns of NTU-MV cells. (A) Esterase, (B) MDH, and (C) LDH. Lanes 1-5 are, respectively, NTU-PN-HF, IPLB-LD-652Y, NTU-MV, NTU-MV1, and NTU-MV56. Lanes 6 and 7 show results for MV and Sf9 cells cultured in serum-free Sf900 medium.

the round cells were much higher than in the other three cell types. For NTU-MV, the virus titer, ranged from $1.3 \times 10^{7}$ to $2.29 \times 10^{8} \mathrm{TCID}_{50} / \mathrm{ml}$. The other three MaviMNPV-infected cell lines, NTU-PN-HH, LY, and LD7 showed no apparent cytopathic effect. In serum-free Sf900 medium, MaviMNPV could infect NTU-MV cells and several Sf9 cells too.

\subsection{Electron microscopy}

The morphogenesis and infectivity of MaviMNPV in vitro was similar to that reported in vivo by Lee et al. (2007). After 3 days postinfection, nucleocapsids, multiple nucleocapsid virions, virogenic stroma, and developing polyhedra were observed in the hypertrophied nuclei, and an electron-dense mass was seen in the cytoplasm (Fig. 7). The ultrastructural morphogenesis of MaviMNPV in vitro is typical of an NPV.

\subsection{Infection rate of $M V$ cells with MaviMNPV}

Over $80 \%$ of the MV1 and MV56 cells were infected with MaviMNPV at five days postinfection, but MV cells 

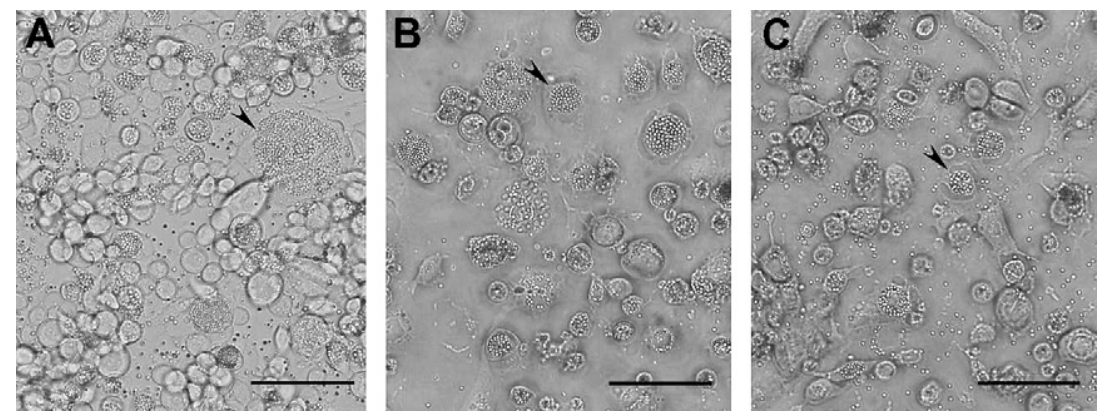

Fig. 6. Production of MaviMNPV occlusion bodies (arrowheads) at 4 days postinfection in (A) MV, (B) MV1 and (C) MV56 cells. Bar: $50 \mu \mathrm{m}$.

in the same $8 \%$ FBS medium did not reach this level of infection until the following day (6 dpi) (Fig. 8). By contrast, in Sf900 medium, infection rates in the MV cells approached $80 \%$ at four days postinfection.

\subsection{Production of occlusion bodies and extracellular virus}

MV cells cultured in medium supplemented with $4 \%$, $6 \%, 8 \%$, and $10 \%$ FBS produced $1.54-2.43 \mathrm{OBs} / \mathrm{cell}$ $\left(1.57-2.87 \times 10^{6} \mathrm{OBs} / \mathrm{ml}\right)$ at 1 week postinfection and $33.76-53.03 \mathrm{OBs} / \mathrm{cell}\left(2.86-4.49 \times 10^{7} \mathrm{OBs} / \mathrm{ml}\right)$ at 2 weeks
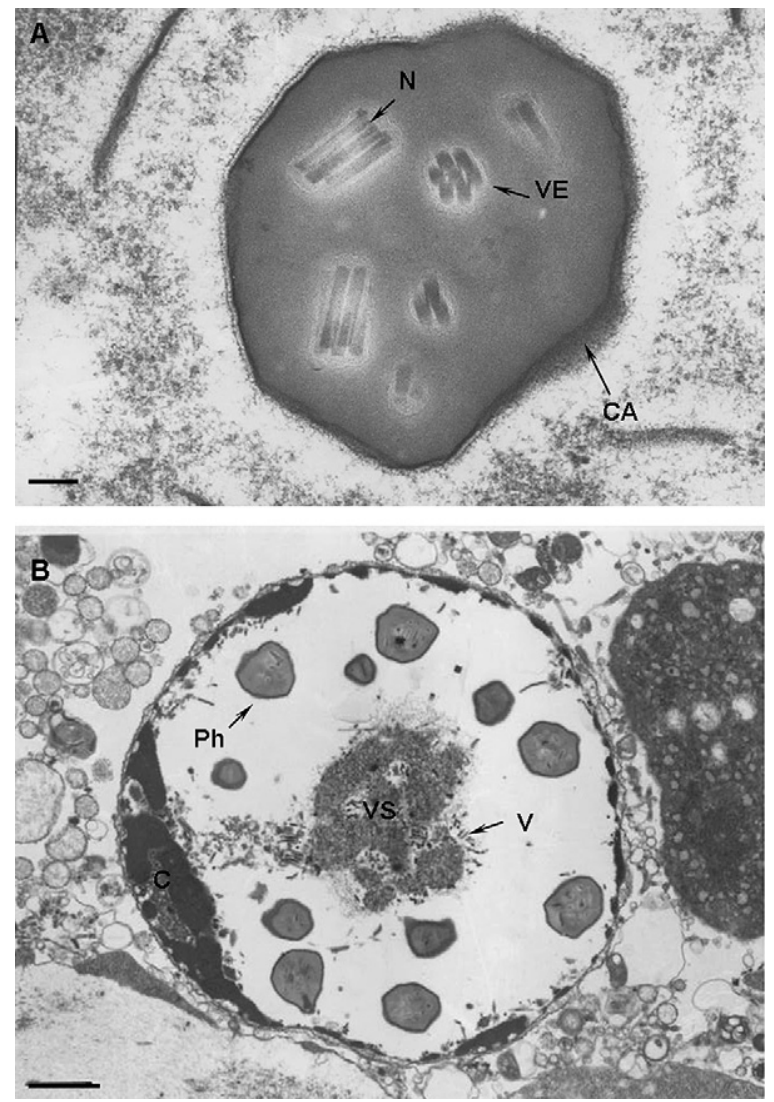

Fig. 7. (A) A MaviMNPV occlusion body. (B) A MaviMNPV-infected MV cell at 3 days postinfection. N, nucleocapsid; VE, virion; CA, calyx; $\mathrm{Ph}$, polyhedron; VS, virogenic stroma; V, virion; envelope; $\mathrm{C}$, chromosome mass. Bar: (A) $100 \mathrm{~nm}$; (B) $1 \mu \mathrm{m}$.

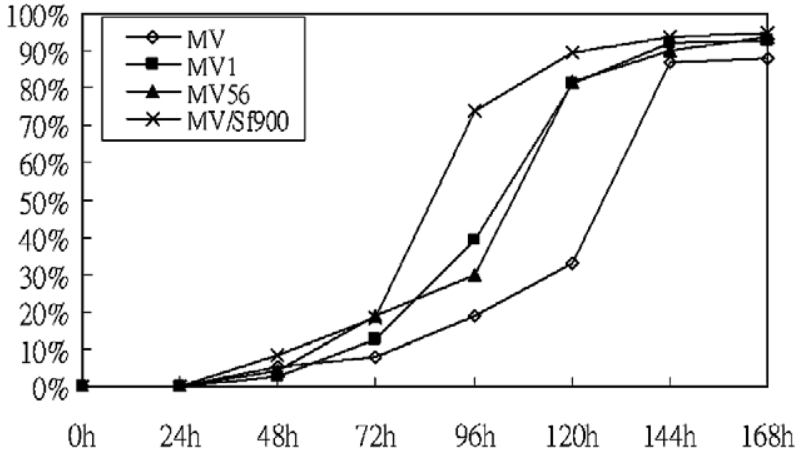

Fig. 8. The percentage of MV, MV1, and MV56 cells infected with MaviMNPV at one to seven days postinfection.

postinfection (Fig. 9A). There was no significant difference between the OB yields at $8 \%$ and $10 \%$ FBS. With an $8 \%$ FBS supplement, MV1 cells produced $3.5 \pm 0.24$ $(\mathrm{X} \pm \mathrm{SD}) \mathrm{OBs} /$ cell $\left(4.19 \times 10^{6} \mathrm{OBs} / \mathrm{ml}\right)$ at 1 week postinfection and $47.23 \pm 2.45 \mathrm{OBs} / \mathrm{cell}\left(5.47 \times 10^{7} \mathrm{OBs} / \mathrm{ml}\right)$ at 2 weeks postinfection. MV56 cells produced $24.96 \pm 1.44$ $(\mathrm{X} \pm \mathrm{SD}) \mathrm{OBs} /$ cell $\left(2.99 \times 10^{6} \mathrm{OBs} / \mathrm{ml}\right)$ at 1 week postinfection and $49.86 \pm 1.53 \mathrm{OBs} / \mathrm{cell}\left(5.96 \times 10^{7} \mathrm{OBs} / \mathrm{ml}\right)$ at 2 weeks postinfection. There were no significant differences in OB production among the MV, MV1, and MV56 cells at 2 weeks postinfection, but MV56 cells produced significantly more OBs than MV and MV1 cells at 1 week postinfection (Fig. 9B). Compared to the FBS-cultured cells, MV cells cultured in serum-free Sf900 medium produced significantly fewer OBs $(23.95 \pm 0.83 \mathrm{OBs} / \mathrm{cell}$ and $\left.2.59 \times 10^{7} \mathrm{OBs} / \mathrm{ml}\right)$ at 2 weeks postinfection. The extracellular virus (ECV) titers of MaviMNPV-infected MV, MV1, and MV56 in TNM-FH medium and MaviMNPVinfected MV in Sf900 medium (MV/Sf900) cells ranged from $1.7 \times 10^{7}$ to $1.69 \times 10^{8}, 3.16 \times 10^{7}$ to $4.64 \times 10^{7}$, $5.01 \times 10^{7}$ to $7.17 \times 10^{8}$, and $6.31 \times 10^{6}$ to $2.43 \times 10^{7}$ $\mathrm{TCID}_{50} / \mathrm{ml}$ at 1 week postinfection, respectively. The extracellular virus (ECV) titers of MaviMNPV-infected MV, MV1, and MV56 in TNM-FH medium, and MaviMNPV-infected MV in Sf900 medium (MV/Sf900) cells ranged from $3.83 \times 10^{7}$ to $2.43 \times 10^{8}, 4.7 \times 10^{7}$ to $2.51 \times 10^{8}, \quad 7.94 \times 10^{7}$ to $1.95 \times 10^{8}$, and $1.7 \times 10^{8}$ to $2.25 \times 10^{8} \mathrm{TCID}_{50} / \mathrm{ml}$ at 2 weeks postinfection, respectively (Table 1). 

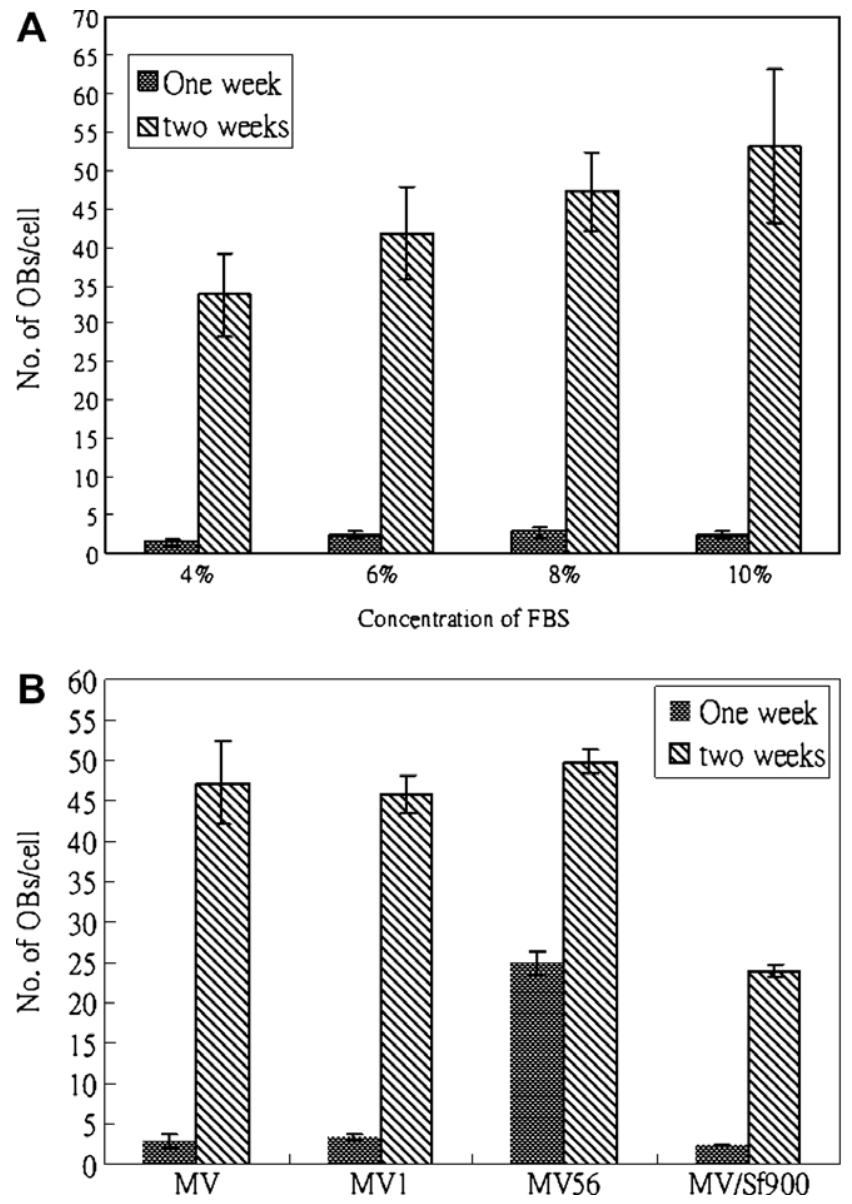

Fig. 9. (A) Production of occlusion bodies in MaviMNPV-infected MV cells cultured with TNM-FH medium supplemented with different concentrations of FBS. (B) Production of MaviMNPV occlusion bodies in MV, MV1, and MV56 cells in 8\% FBS, and in MV cells cultured in Sf900 medium.

\subsection{RELP (restriction endonuclease length polymorphism) of viral DNAs}

The RELP of the MaviMNPV DNAs purified from moribund $M$. vitrata larvae and from infected $\mathrm{MV}$ cells were identical for EcoRI, HindIII, and Pst I digestions (Fig. 10).

\section{Discussion}

We have described here how pupal ovary tissues from $M$. vitrata were successfully used to establish a new cell line designated NTU-MV (National Taiwan University). The isozyme patterns (Tabachnick and Knudson, 1980) of

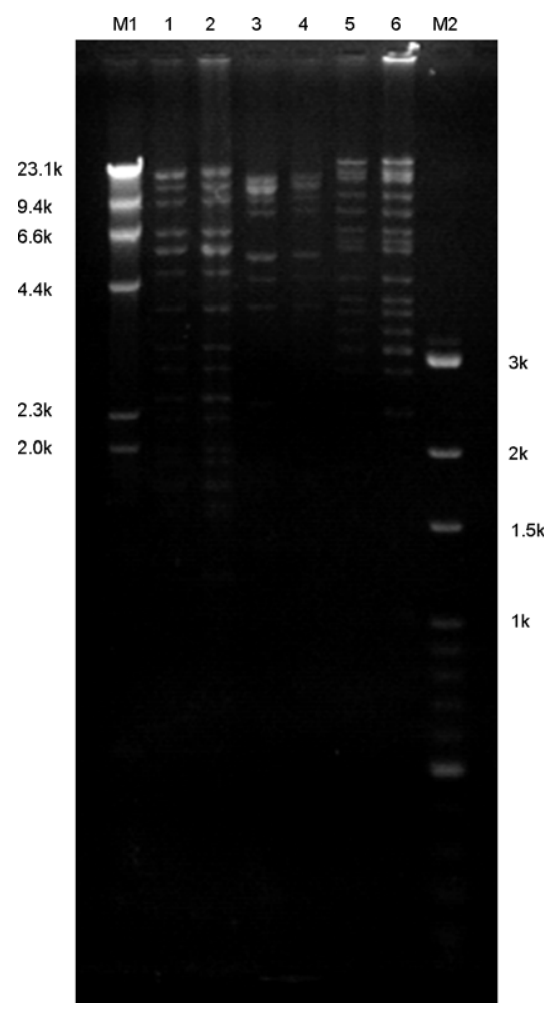

Fig. 10. Restriction endonuclease patterns, EcoRI (lanes 1 and 2), HindIII (lanes 3 and 4), and PstI (lanes 5 and 6), for MaviMNPV DNAs purified in vivo (lanes 1, 3, and 5) from infected larvae of $M$. vitrata and in vitro from infected NTU-MV cells (lanes 2, 4, and 6). M1 is $\lambda$ DNA/HindIII commercial marker, and M2 is another commercial marker (Genemark).

NTU-MV cells and those of its two cell strains, MV1 and MV56, were distinct from those of other cell lines (Fig. 5), while alignment of the rDNA ITS regions (Gunderson et al., 1987) showed a high identity (98\%) between the MV and pupal sequences, which confirms that the MV cell line was derived from M. vitrata. We further showed that the NTU-MV, NTU-MV1, and NTU-MV56 cell lines were all highly susceptible to MaviMNPV (Fig. 8) and were able to replicate the virus (Figs. 6, 7, and 9). Fig. 6 further shows that almost all of the MaviMNPV that infected the MV, MV1, and MV56 cells was an MP (multiple polyhedra) strain, with an FP (few polyhedra) strain being found only in one or two infected cells. The identity of the virus was confirmed by restriction enzymes profiles (Smith and Summers, 1978; de Moraes and Maruniak, 1997), which showed that the MaviMNPV DNAs purified from in vitro and in vivo sources, were from the same virus (Fig. 10).

The round MV cells are $\sim 20 \%$ smaller than IPLB-LD cells (Goodwin et al., 1978), IPLB-SF 21 cells (Vaughn

Table 1

The extracellular virus (ECV) titers of MaviMNPV-infected MV, MV1, MV56 in TNM-FH medium, and MV cells in serum free medium Sf900

\begin{tabular}{lllll}
\hline & MV & MV1 & MV56 & MV/Sf900 \\
\hline 1 week & $1.70 \times 10^{7}-1.69 \times 10^{8}$ & $3.16 \times 10^{7}-4.64 \times 10^{7}$ & $5.01 \times 10^{7}-7.17 \times 10^{7}$ & $6.31 \times 10^{6}-2.43 \times 10^{7}$ \\
2 weeks & $3.83 \times 10^{7}-2.43 \times 10^{8}$ & $4.70 \times 10^{7}-2.51 \times 10^{8}$ & $7.94 \times 10^{7}-1.95 \times 10^{8}$ & $1.70 \times 10^{8}-2.25 \times 10^{8}$ \\
\hline
\end{tabular}


et al., 1977), and UCR-SE-1 cells (Gelernter and Federici, 1986), and the spindle-shaped cells of MV cells are $~ 35$ $45 \%$ smaller than these other cell lines. The sizes of the MV cell types are not significantly different from the corresponding cell types in the MV1 and MV56 strains. However, as noted above, the percentages of the four cell types are different in these three cell lines (Fig. 2), and this probably explains why MV56 showed a higher level of OB production after 1 week (Fig. 9B) than MV1 or its parent cells (NTU-MV).

MaviMNPV is the first baculovirus to be found in M. vitrata (Lee et al., 2007) and this pathogen could be used as a very effective biocontrol of this major pest. Here we have shown that the NTU-MV cell line and its stains potentially provide an efficient MaviMNPV propagation system for both the study and production of MaviMNPV. We note that the high cost of serum is a serious limitation to the commercial production of viral insecticide in vitro. However, halving the amount of FBS from 16\% to $8 \%$ had no significant effect on NTU-MV growth curves (Fig. 3), and 8\% FBS also produced a high yield of OBs $(\sim 47 \mathrm{OBs} /$ cell, $4 \times 10^{7} \mathrm{OBs} / \mathrm{ml}$ ) after 2 weeks postinfection (Fig. 9). Probably because of the high proportion of MaviMNPV-susceptible round cells, the NTU-MV56 cell line produced a high number of OBs $\left(\sim 25 \mathrm{OBs} / \mathrm{cell}, 2.99 \times 10^{6} \mathrm{OBs} / \mathrm{ml}\right)$ at 1 week postinfection (Fig. 9B); and this is important because when recombinant protein is purified from infected insect cells, the presence of serum makes the downstream purification and recovery process difficult (Wang et al., 1992). Taken together, we conclude that the MaviMNPV/MV cell system is an excellent tool to study the basic biology of the cells and virus, and it could also potentially be developed into a new BEVS (baculovirus expression vector system) to product recombinant proteins.

\section{Acknowledgments}

This study was supported by the National Science Council, Republic of China under Grant Nos. NSC 95-2313-B-002-038 and NSC 95N-1302.

\section{References}

Afun, J.V.K., Jackai, L.E.N., Hodgson, C.J., 1991. Calendar and monitored insecticide application for the control of cowpea pests. Crop Prot. 10, 363-370.

AVRDC, 2005. AVRDC Annual Report 2004. Asian Vegetable Research and Development Center, Shanhua, Tainan, Taiwan.

Booker, R.H., 1965. Pest of cowpea and their control in North Nigeria. Bull. Entomol. Res. 56, 663-672.

de Moraes, R.R., Maruniak, J.E., 1997. Detection and identification of multiple baculoviruses using the polymerase chain reaction (PCR) and restriction endonuclease analysis. J. Virol. Methods 63, 209-217.

Dreyer, H., Baumgartner, J., Tamo, M., 1994. Seed damaging field pests of cowpea (Vigna unguiculata L. Walp.) in Benin: occurrence and pest status. Int. J. Pest Manag. 40, 252-260.

Gelernter, W.D., Federici, B.A., 1986. Continuous cell line from Spodoptera exigua (Lepidoptera: Noctuidae) that supports replication of nuclear polyhedrosis viruses from Spodoptera exigua and Autographa californica. J. invertebr. Pathol. 48, 199-207.
Goodwin, R.H., Tropkins, F.J., McCawley, P., 1978. Gypsy moth cell lines divergent in viral susceptibility. In Vitro 14, 485-494.

Grace, T.D.C., 1962. Establishment of four strains of cells from insect tissues grown in vitro. Nature 195, 788-789.

Gunderson, J.H., Elwood, H., Ingold, A., Kindle, K., Sogin, M.L., 1987. Phylogenetic relationships between chlorophytes, chrysophytes, and oomycetes. Proc. Natl. Acad. Sci. USA 16, 5823-5827.

Hink, W.F., 1970. Established insect cell line from the cabbage looper, Trichoplusia ni. Nature 226, 466-467.

Hink, W.F., Strauss, E., 1976. Growth of the Trichoplusia ni (TN-368) cell line in suspension culture. In: Kurstak, E., Maramorosch, K. (Eds.), Invertebrate Tissue Culture, Applications in Medicine, Biology, and Agriculture. Academic Press, New York, pp. 297-300.

Huang, C.C., Peng, W.K., 2001. Emergence, mating, and oviposition of the bean podborer, Maruca vitrata (F.) (Lepidoptera: Pyralidae). Formos. Entomol. 21, 37-45 (in Chinese with English summary).

Huang, C.C., Peng, W.K., Talekar, N.S., 2003. Parasitoids and other natural enemies of Maruca vitrata feeding on Sesbania cannabina in Taiwan. Biocontrol 48, 407-416.

Koehler, C.S., Metha, P.N., 1972. Relationships of insect control attempts by chemicals to components of yield of cowpea in Uganda. J. Econ. Entomol. 65, 1421-1427.

Lee. S.T., Srinivasan, R., Lo, Y.J., Talekar, N.S., 2007. Identification, characterization and bioassays of Maruca vitrata Multiple Nucleopolyhedrovirus (MaviMNPV) against Maruca vitrata (Lepidoptera: Pyralidae). BioControl, accepted for publication.

Lynn, D.E., 2001. Novel techniques to establish new insect cell lines. In Vitro Cell Dev. Biol. Anim. 37, 319-321.

Manchenko, F.P., 2003. Handbook of Detection of Enzymes on Electrophoretic Gels. CRC Press, London, 285 pp.

Passlow, T., 1968. Navy bean pest. Qld. Agric. J. 94, 762-763.

Saxena, H.P., 1978. Pests of grain legumes and their control in India. In: Singh, S.R., van Emden, H.F., Taylor, R.A. (Eds.), Pests of Grain Legumes: Ecology and Control. Academic Press, London, pp. 15-23.

Singh, S.R., van Emden, H.F., 1979. Insect pests of grain legumes. Annu. Rev. Entomol. 24, 255-278.

Singh, S.R., Jackai, L.E.N., dos Santos, J.H.R., Adalla, C.B., 1990. Insect pests of cowpeas. In: Singh, S.R. (Ed.), Insect Pests of Tropical Food Legumes. John \& Sons, New York, pp. 43-89.

Smith, G.E., Summers, M.D., 1978. Analysis of baculovirus genomes with restriction endonuclease. Virology $89,517-527$.

Summers, M.D., Smith, G.E., 1988. A manual of methods for baculovirus vectors and insect cell culture procedure. Tex. Agric. Exp. Station 1555, 57.

Tabachnick, W.J., Knudson, D.L., 1980. Characterization of invertebrate cell lines. II. Isozyme analysis electrophoresis. In Vitro 16, 392-398.

Taylor, T.A., 1967. The bionomics of Maruca testulalis G $a$ y. (Lepidoptera: Pyralidae), a major pest of cowpea in Nigeria. J.W. Afr. Sci. Assoc. 12, 111-129.

Theilmann, D.A., Blissard, G.W., Bonning, B., Jehle, J., O'Reilly, D.R., Rohrmann, G.F., Thiem, S., Vlak, J.M., 2005. The double stranded DNA viruses. In: Fauquent, C.M., Mayo, M.A., Maniloff, J., Desselberger, U., Ball, L.A. (Eds.), Virus Taxonomy Classification and Nomenclature of Viruses. Academic Press, San Diego, pp. 177-185.

Vaughn, J.L., Goodwin, R.H., Tompkins, G.J., McCawley, P., 1977. The establishment of two cell lines from the insect Spodoptera frugiperda (Lepidoptera: Noctuidae). In Vitro 13, 213-217.

Wang, C.H., Chou, C.M., Liu, H.C., Kau, S.L., Kou, G.H., Lo, C.F., 1996. Continuous cell line from pupal ovary of Perina nuda (Lepidoptera: Lymantriidae) that is permissive to nuclear polyhedrosis virus from $P$. nuda. J. Invertebr. Pathol. 67, 199-204.

Wang, P., Granados, R.R., Shuler, M.L., 1992. Studies on serum-free culture of insect cells for virus propagation and recombinant protein production. J. Invertebr. Pathol. 59, 46-53.

White, T.J., Bruns, T., Lee, S., Taylor, J., 1990. Amplification and direct sequencing of fungal ribosomal RNA genes for phylogenetics. In: Innis, M.A., Gelfand, D.H., Sninsky, J.J., White, J.J. (Eds.), PCR Protocols: A Guide to Methods and Applications. Academic Press, San Diego, pp. 315-322. 
Wu, C.Y., Wang, C.H., 2005. Characterization and polyhedron gene cloning of Lymantria xylina multiple nucleopolyhedrovirus. J. Invertebr. Pathol. 88, 238-246.

Wu, C.Y., Wang, C.H., 2006. New cell lines from Lymantria xylina (Lepidoptera: Lymantriidae): characterization and susceptibility to baculoviruses. J. Invertebr. Pathol. 93, 186-191.
Wu, C.Y., Yang, H.N., Lo, C.F., Wang, C.H., 2002. A Perina nuda cell line (NTU-Pn-HF) from pupal ovary that is persistently infected with a picorna-like virus (PnPV). Appl. Entomol. Zool. 37, 171-179.

Wu, J., King, G., Daugulis, A.J., Faulkner, P., Bone, D.H., Goosen, M.F.A., 1989. Engineering aspects of insect cell suspension culture: a review. Microbiol. Biotechnol. 32, 249-255. 